\title{
CONTENT AND CHEMICAL COMPOSITION OF THE ESSENTIAL OIL OF Myrcia lundiana Kiaersk IN DIFFERENT DRYING TIMES
}

\author{
TEOR E COMPOSIÇÃO QUÍMICA DO ÓLEO ESSENCIAL DE Myrcia lundiana \\ Kiaersk EM DIFERENTES TEMPOS DE SECAGEM
}

\author{
Mércia Freitas ALVES ${ }^{1}$; Arie Fitzgerald BLANK ${ }^{2}$; Thiago Matos ANDRADE ${ }^{3}$; \\ Daniela Aparecida de Castro NIZIO ${ }^{4}$; Taís Santos SAMPAIO ${ }^{4}$; \\ Alberto Ferreira de NASCIMENTO JUNIOR
}

1. Pós-doutoranda em Agronomia da Universidade Federal de Uberlândia, Campus Umuarama, Uberlândia, MG, Brasil. merciafreitas.alvs@gmail.com; 2. Professor do Departamento de Engenharia Agronômica, Universidade Federal de Sergipe, Av. Marechal Rondon s/n, São Cristóvão, Brasil. 3. Professor Adjunto, Doutor, Campus do Sertão - UFS, Nossa Senhora da Glória, SE, Brasil; 4. Doutora em Biotecnologia, Universidade Federal de Sergipe - UFS, São Cristovão, SE, Brasil. 5. Mestrando em Agricultura e Biodiversidade, UFS, São Cristovão, SE, Brasil.

\begin{abstract}
This study aimed to evaluate the effect of the leaves drying time on the content and chemical composition of the essential oil of $M$. lundiana. Treatments consisted of drying times of $0,1,2,3,4,5,6,8$, and 10 days, at $40^{\circ} \mathrm{C}$, in a forced-air-circulation oven. Essential oils were obtained by hydrodistillation using the Clevenger apparatus, and chemical composition analysis was performed by GC-MS/FID. The drying process of M. lundiana leaves did not cause significant variations in the oil content, ranging from 1.18 to $1.51 \%$. Nerolic acid was the major compound, ranging from $27.8 \%$ (at six days of drying) to $35.64 \%$ (at ten days of drying). The compound 1,8-cineole was identified as the second major compound of the essential oil, ranging from $9.04 \%$ to $14.01 \%$. Other major compounds found in the essential oils were $\alpha$-terpineol (7.12-8.41\%), $\beta$-pinene (5.08- 9.03\%), Z- $\alpha$-trans-bergamotol (5.40-7.57\%), and caryophyllene oxide $(4.12-7.11 \%)$. One day of leaves drying at $40^{\circ} \mathrm{C}$ was sufficient to reach the recommended foliar moisture level without significantly altering the content and chemical composition of the essential oil of M. lundiana or the contents of the major compounds of the essential oil.
\end{abstract}

KEYWORDS: Native aromatic plant. Chemical compounds. Drying. Influence.

\section{INTRODUCTION}

Myrcia lundiana Kiaersk (Myrtaceae) is a medicinal and aromatic shrub or small tree of up to $6 \mathrm{~m}$ high, found in tropical and subtropical areas of the southern hemisphere (GOVAERTS et al., 2008). The chemical composition and the qualitative and quantitative characteristics of its essential oil varies. This study revealed a variety of 24 compounds in its essential oil, and the main compounds were: $\alpha$ pinene, $\beta$-pinene, 1,8-cineole, linalool, isopulegol, iso-isopulegol, neral, geranial and nerolic acid (ALVES et al., 2016).

The existence of different chemical groups was observed in $M$. lundiana, being three essential oil chemotypes, nerolic acid type, and isopulegol and citral type (ALVES et al., 2016). In this way, the components nerolic acid, isopulegol, and citral can help the quality control of this oil by distinguishing substitutes or adulterants.

In aromatic and medicinal species, the plant is dried to minimize the loss of active principles and to delay the deterioration of the material. The reduction of the amount of water in the tissues decreases the enzymatic activity, allowing the conservation of the plant material for a longer period for its further commercialization and use (COSTA et al., 2005). Each species presents a distinct drying process, which can be carried out under environmental or artificial conditions using a drying oven. Some factors must be taken into account when determining the drying conditions of an aromatic species, such as the sensitivity of the essential oil compounds and the storage structures of the plant; the characteristics of the plant (woody or herbaceous); the leaf thickness; and the purpose of the essential oil (NAGAO et al., 2005).

The drying process can influence the quantity and quality of the essential oil for they are constituted by volatile compounds, which are very sensitive to the increase in temperature. Inadequate drying can lead to losses in the content of the active principle of the essential oil and thus alter its pharmacological activity (LUZ et al., 2009).

Some works have reported the influence of the drying process on the characteristics of the essential oil of several species. Alves et al. (2015) observed that the drying time significantly influenced the chemical composition regarding the linalool content and the essential oil content of the basil cultivar Maria Bonita (Ocimum basilicum L.). Parmar et al. (2017), in a comparative study on the 
drying process of maize leaves, observed that a better leaf drying is achieved when the operation is carried out in the fluidized bed dryer at $45^{\circ} \mathrm{C}$ for the 30 s counterbalanced steam sample.

Blank et al. (2005) observed that the drying process of Melissa officinalis leaves increased the contents of the major compounds $\beta$-citral and $\alpha$ citral, but reduced the contents of terpene, nerol, and geraniol, which are the most valued compounds in the species. This study aimed to evaluate the influence of the drying time on leaf moisture reduction, content, and chemical composition of the essential oil of Myrcia lundiana.

\section{MATERIAL AND METHODS}

\section{Plant material}

Leaves of M. lundiana were collected in the National Park of Itabaiana. The Park is located in the municipalities of Areia Branca, Itabaiana, Laranjeiras, Itaporanga D'ajuda, and Campo do Brito, in the state of Sergipe, northeastern Brazil

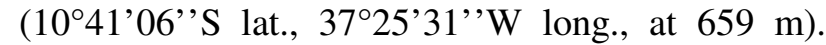
The area covers $7966 \mathrm{ha}$ and an $87.25 \mathrm{~km}$ perimeter, comprising the regions of Serras Cajueiro, Comprida, and Itabaiana. The park is located in a transition zone between the Brazilian caatinga and the rainforest, and the predominant climate of the basin where it is located is semi-arid with annual rainfall ranging between 1100 and $1300 \mathrm{~mm}$ in welldefined seasons, and average monthly relative humidity of $84.6 \%$. The climate consists of four to five months of drought, and it is a semi-arid climate, with temperatures up to $35^{\circ} \mathrm{C}$, which is hotter than Aracaju, the capital of the state of Sergipe (IBAMA, 2006).

\section{Extraction and analysis of essential oils}

Samples of $100 \mathrm{~g}$ of fresh leaves were used in a completely randomized design with three replications. The treatments consisted of drying times of $0,1,2,3,4,5,6,8$, and 10 days at $40^{\circ} \mathrm{C}$ in a forced-air-circulation oven type SOLAB SL 102. The essential oils were extracted by hydrodistillation in a modified Clevenger apparatus. Samples of dried leaves were distilled in triplicate for 140 minutes (EHLERTH et al., 2006). The essential oils were stored in amber flasks at $-20{ }^{\circ} \mathrm{C}$ until chemical composition analysis. The moisture content of each treatment was obtained from three samples of $100 \mathrm{~g}$ of fresh leaves, dried at $105^{\circ} \mathrm{C}$ to a constant weight. To calculate the moisture content, fresh and dried leaves were weighed, resulting in a value in $(\%)$ of water loss.
The analysis of the chemical composition of the essential oils was carried out using a GCMS/FID (QP2010 Ultra, Shimadzu Corporation, Kyoto, Japan), equipped with an autosampler AOC20i (Shimadzu). Separations were accomplished using an Rtx ${ }^{\circledR}-5$ MSRestek fused silica capillary column (5\%-diphenyl-95\%-dimethylpolysiloxane) of $30 \mathrm{~m} \times 0.25 \mathrm{~mm}$ i.d., $0.25 \mathrm{~mm}$ film thickness, at a constant helium $(99.999 \%)$ flow rate of $1.2 \mathrm{~mL}$ $\mathrm{min}^{-1}$. An injection volume of $0.5 \mu \mathrm{L}\left(5 \mathrm{mg} \mathrm{mL}^{-1}\right)$ was employed, with a split ratio of 1:10. The oven temperature was programmed from $50^{\circ} \mathrm{C}$ (isothermal for $1.5 \mathrm{~min}$ ), with an increase of $4^{\circ} \mathrm{C} / \mathrm{min}$ to $200^{\circ} \mathrm{C}$, then $10^{\circ} \mathrm{C} / \mathrm{min}$ to $250^{\circ} \mathrm{C}$, ending with a 5 min isothermal at $25^{\circ} \mathrm{C}$.

The MS and FID data were simultaneously acquired by a Detector Splitting System; the split flow ratio was 4:1 (MS:FID). A $0.62 \mathrm{~m} \times 0.15 \mathrm{~mm}$ i.d. restrictor tube (capillary column) was used to connect the splitter to the MS detector; a $0.74 \mathrm{~m} \times$ $0.22 \mathrm{~mm}$ i.d. restrictor tube was used to connect the splitter to the FID detector. The MS data (total ion chromatogram, TIC) were acquired in full scan mode $(\mathrm{m} / \mathrm{z}$ of $40-350)$, at a scan rate of $0.3 \mathrm{scan} / \mathrm{s}$, using the electron ionization (EI), with an electron energy of $70 \mathrm{eV}$. The injector temperature was $250^{\circ} \mathrm{C}$, and the ion-source temperature was $250^{\circ} \mathrm{C}$. The FID temperature was set to $250^{\circ} \mathrm{C}$, and the gas supplies for the FID were hydrogen, air, and helium

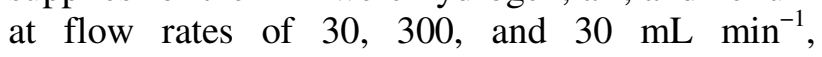
respectively. Quantification of each compound was estimated by FID peak-area normalization (\%). Compound concentrations were calculated from the GC peak areas and arranged in order of GC elution.

Identification of individual components of the essential oil was carried out by computerized matching of the acquired mass spectra with those stored in the NIST21, NIST107, and WILEY8 mass spectral library of the GC-MS data system. A mixture of hydrocarbons $\left(\mathrm{C}_{9} \mathrm{H}_{20}-\mathrm{C}_{19} \mathrm{H}_{40}\right)$ was injected under these same conditions, and compounds identification was then performed by comparing the spectra obtained in the present study with those of the equipment data bank, and by the retention index, calculated for each component, as previously described (ADAMS, 2007). Retention indices were calculated using the equation proposed by Van Den Dool and Kratz (1963).

\section{Statistical analysis}

The data were subject to analysis of variance (ANOVA), and means were grouped by the Scott-Knott test $(\mathrm{p}<0.05)$ to determine the essential oil content and chemical composition in function of the storage environment. 


\section{RESULTS AND DISCUSSION}

The initial moisture content of fresh leaves of $M$. lundiana was $49.4 \%$. From the first day of drying, a sharp decrease was observed in the water content of the leaves, reaching $3.17 \%$ of moisture and remaining constant on other days. The moisture data considering the drying times were adjusted to the exponential model (Figure 1).

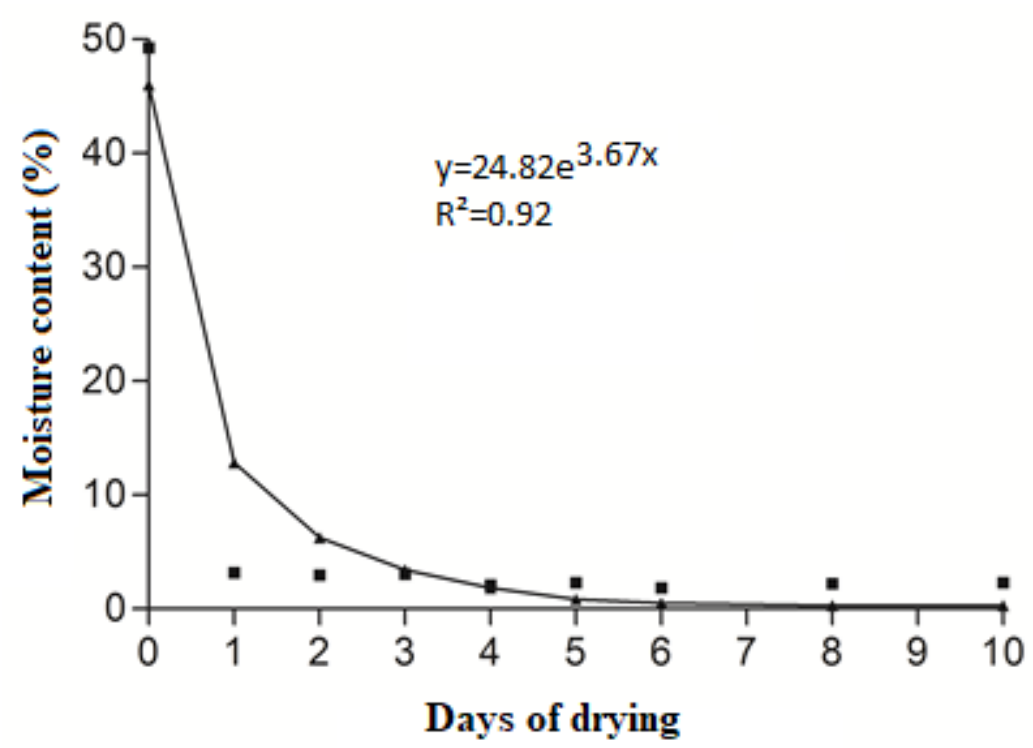

Figure 1. Variation of leaves moisture of Myrcia lundiana in different drying times.

One day of drying was enough to obtain leaves moisture below 5\% for M. lundiana. Alves et al. (2015), evaluated the drying and storage of basil leaves and observed that four days of drying at 40 ${ }^{\circ} \mathrm{C}$ is the ideal time to stabilize the moisture of basil leaves. These results contradict that observed in a study with a sweet basil cultivar, where leaves and inflorescences lost almost all moisture content after one day of drying (CARVALHO-FILHO et al., 2006).
No significant difference was observed for the essential oil content of $M$. lundiana at different drying times (Table 1). Blank et al. (2007) verified a significant increase in the essential oil yield when studying citronella (Cymbopogon winterianus). In contrast, Luz et al. (2009) observed a significant decrease in the essential oil content of Ocimum gratissimum L obtained from fresh leaves when compared with that obtained on the eighth day of drying.

Table 1. Essential oil content of Myrcia lundiana, according to drying time at $40^{\circ} \mathrm{C}$.

\begin{tabular}{ccccccccc}
\hline \multicolumn{10}{c}{ Drying time (days) } \\
\hline $\mathbf{0}$ & $\mathbf{1}$ & $\mathbf{2}$ & $\mathbf{3}$ & $\mathbf{4}$ & $\mathbf{5}$ & $\mathbf{6}$ & $\mathbf{8}$ & $\mathbf{1 0}$ \\
\hline $1.51 \mathrm{a}$ & $1.11 \mathrm{a}$ & $1.18 \mathrm{a}$ & $1.18 \mathrm{a}$ & $1.24 \mathrm{a}$ & $1.18 \mathrm{a}$ & $1.31 \mathrm{a}$ & $1.24 \mathrm{a}$ & $1.31 \mathrm{a}$ \\
\hline
\end{tabular}

For Myrcia lundiana, essential oil storage and release may occur in structures located inside the leaves, such as secretory structures. Santana et al. (2014), in a study on the essential oil content of Ocimum gratissimum, observed a rupture of the trichomes during the drying process due to their structural fragility, which consequently increased the vulnerability to external conditions, especially those related to harvesting, processing, and drying methods. The same happened in a study on the influence of the drying method on the floral structures of chamomile, where a predisposition to essential oil loss was reported, reducing the moisture and essential oil content of the plant during the drying method (BORSATO et al., 2008).

Thirty-four compounds were identified in the essential oil of M. lundiana (Table 2). The most abundant compounds were: nerolic acid, 1,8cineole, $\alpha$-terpineol, $\beta$-pinene, Z- $\alpha$-trans-bergamotol and caryophyllene oxide. 
Table 2. Chemical composition of the essential oil of Myrcia lundiana according to the drying time.

\begin{tabular}{|c|c|c|c|c|c|c|c|c|c|c|c|}
\hline \multirow{2}{*}{ Compound } & \multirow{2}{*}{ IRRI* } & \multirow{2}{*}{ IRRL* } & \multicolumn{9}{|c|}{ Drying time (days) } \\
\hline & & & $\mathbf{0}$ & 1 & 2 & 3 & 4 & 5 & 6 & 8 & 10 \\
\hline$\alpha$-thujene & 945 & 924 & 0.11 & 0.00 & 0.00 & 0.00 & 0.00 & 0.08 & 0.10 & 0.00 & 0.07 \\
\hline$\alpha$-pinene & 951 & 932 & 3.59 & 3.31 & 4.37 & 3.38 & 3.00 & 4.82 & 4.12 & 3.40 & 3.21 \\
\hline Canphene & 961 & 946 & 0.13 & 0.00 & 0.00 & 0.00 & 0.00 & 0.00 & 0.00 & 0.00 & 0.00 \\
\hline$\beta$-pinene & 986 & 974 & 6.23 & 6.20 & 7.32 & 5.76 & 5.08 & 8.20 & 9.03 & 5.92 & 5.61 \\
\hline Myrcene & 994 & 988 & 0.19 & 0.00 & 0.00 & 0.00 & 0.00 & 0.00 & 0.11 & 0.00 & 0.11 \\
\hline$\delta$-3-carene & 1012 & 1008 & 0.07 & 0.00 & 0.00 & 0.00 & 0.00 & 0.00 & 0.00 & 0.00 & 0.00 \\
\hline$\rho$-cymene & 1026 & 1020 & 0.80 & 1.01 & 1.11 & 0.84 & 0.68 & 1.25 & 1.39 & 0.84 & 0.80 \\
\hline Limonene & 1031 & 1024 & 1.11 & 1.02 & 1.19 & 0.89 & 0.74 & 1.46 & 1.85 & 0.89 & 1.02 \\
\hline 1,8-cineole & 1035 & 1026 & $\begin{array}{l}11.2 \\
2\end{array}$ & $\begin{array}{l}12.3 \\
4\end{array}$ & $\begin{array}{l}12.8 \\
0\end{array}$ & $\begin{array}{l}11.1 \\
7\end{array}$ & $\begin{array}{l}11.1 \\
4\end{array}$ & $\begin{array}{l}11.8 \\
0\end{array}$ & $\begin{array}{l}14.1 \\
0\end{array}$ & $\begin{array}{l}11.2 \\
7\end{array}$ & 9.04 \\
\hline$\Upsilon$-terpinene & 1060 & 1054 & 0.33 & 0.29 & 0.30 & 0.20 & 0.13 & 0.32 & 0.64 & 0.18 & 0.26 \\
\hline Terpinolene & 1091 & 1087 & 0.78 & 0.41 & 0.44 & 0.43 & 0.40 & 0.59 & 0.73 & 0.43 & 0.51 \\
\hline Linalool & 1102 & 1095 & 1.72 & 1.57 & 1.44 & 1.60 & 1.61 & 1.48 & 1.57 & 1.50 & 1.53 \\
\hline Endo-fenchol & 1117 & 1114 & 0.30 & 0.37 & 0.32 & 0.31 & 0.30 & 0.26 & 0.23 & 0.25 & 0.23 \\
\hline Trans- pinocarveol & 1142 & 1135 & 0.30 & 0.39 & 0.36 & 0.36 & 0.37 & 0.37 & 0.23 & 0.32 & 0.29 \\
\hline Isopulegol & 1147 & 1145 & 0.18 & 0.00 & 0.00 & 0.05 & 0.00 & 0.00 & 0.00 & 0.00 & 0.00 \\
\hline Neo-isopulegol & 1148 & 1143 & 0.06 & 0.12 & 0.00 & 0.00 & 0.00 & 0.00 & 0.00 & 0.07 & 0.00 \\
\hline Iso-isopulegol & 1158 & 1155 & 0.08 & 0.00 & 0.00 & 0.00 & 0.00 & 0.00 & 0.00 & 0.00 & 0.00 \\
\hline Borneol & 1170 & 1165 & 0.40 & 0.47 & 0.45 & 0.42 & 0.45 & 0.40 & 0.28 & 0.39 & 0.38 \\
\hline Terpinen-4-ol & 1181 & 1174 & 2.89 & 3.14 & 3.00 & 2.99 & 2.93 & 2.72 & 2.78 & 2.74 & 2.69 \\
\hline$\rho$-cymen-8-ol & 1189 & 1179 & 0.64 & 0.66 & 0.65 & 0.64 & 0.70 & 0.59 & 0.55 & 0.68 & 0.70 \\
\hline$\alpha$-terpineol & 1196 & 1186 & 8.31 & 8.30 & 7.75 & 8.23 & 8.41 & 7.23 & 7.12 & 7.15 & 7.76 \\
\hline Myrtenol & 1201 & 1195 & 0.52 & 0.70 & 0.62 & 0.45 & 0.68 & 0.55 & 0.34 & 0.65 & 0.42 \\
\hline Neral & 1243 & 1223 & 0.30 & 0.20 & 0.20 & 0.22 & 0.20 & 0.19 & 0.15 & 0.21 & 0.21 \\
\hline Carvone & 1246 & 1239 & 0.00 & 0.00 & 0.00 & 0.00 & 0.00 & 0.18 & 0.27 & 0.00 & 0.26 \\
\hline Methyl-citronellate & 1262 & 1257 & 1.63 & 2.06 & 2.03 & 1.77 & 1.71 & 1.86 & 2.02 & 1.81 & 1.60 \\
\hline Geranial & 1273 & 1249 & 0.50 & 0.34 & 0.35 & 0.33 & 0.32 & 0.32 & 0.39 & 0.35 & 0.36 \\
\hline Methyl nerolate & 1282 & 1280 & 0.60 & 0.77 & 0.77 & 0.67 & 0.63 & 0.70 & 0.76 & 1.11 & 0.59 \\
\hline Nerolic acid & 1365 & 1347 & 33.3 & 30.7 & 29.2 & 32.3 & 34.7 & 30.2 & 27.8 & 35.6 & 35.6 \\
\hline & & & 1 & 2 & 4 & 1 & 7 & 5 & 8 & 6 & 4 \\
\hline$E$-caryophyllene & 1424 & 1417 & 1.54 & 0.71 & 0.75 & 0.73 & 0.71 & 0.91 & 1.04 & 0.96 & 1.05 \\
\hline $\begin{array}{l}\text { Trans- } \alpha- \\
\text { bergamotene }\end{array}$ & 1438 & 1436 & 0.34 & 0.09 & 0.11 & 0.11 & 0.06 & 0.18 & 0.08 & 0.22 & 0.15 \\
\hline Spathulene & 1584 & 1577 & 0.48 & 0.68 & 0.68 & 0.64 & 0.71 & 0.63 & 0.45 & 0.64 & 0.60 \\
\hline $\begin{array}{l}\text { Caryophyllene } \\
\text { oxide }\end{array}$ & 1591 & 1582 & 4.52 & 7.11 & 6.97 & 6.76 & 6.38 & 6.40 & 4.12 & 6.32 & 5.87 \\
\hline $\begin{array}{l}\text { Humulene epoxide } \\
\text { II }\end{array}$ & 1617 & 1608 & 0.11 & 0.00 & 0.00 & 0.00 & 0.00 & 0.00 & 0.00 & 0.00 & 0.00 \\
\hline $\begin{array}{l}\text { Cariophyl-4 (12), } 8 \\
\text { (13) -dien-5 } \beta \text {-ol }\end{array}$ & 1644 & 1639 & 1.07 & 1.24 & 1.40 & 1.58 & 1.57 & 1.34 & 0.84 & 1.42 & 1.46 \\
\hline $\begin{array}{l}\text { Z- } \alpha \text {-trans- } \\
\text { bergamotol }\end{array}$ & 1699 & 1713 & 7.57 & 6.50 & 6.20 & 6.75 & 6.19 & 6.08 & 5.40 & 6.15 & 7.34 \\
\hline
\end{tabular}

The monoterpene nerolic acid was the major compound, ranging from $27.88 \%$ at six days of drying to $35.64 \%$ at ten days of drying. This variation oscillated during the drying time. Similar results were observed by Carvalho-Filho et al. (2006) when studying Ocimum basilicum L.. The authors verified that the linalool content in the essential oil increased from $45.18 \%$ to $86.80 \%$ at five days of drying. Rosado et al. (2011) studied the influence of different drying and processing methods on Ocimum basilicum L. leaves and observed a non-significant increase in the major compound linalool when the leaves were dried. The contents ranged from $78.3 \%$ to $84.3 \%$, and the lowest content was obtained from fresh leaves. The compound 1,8-cineole was identified as one of the 
major compounds of the essential oil, ranging from 9.04 to $14.10 \%$. Other major compounds of the essential were $\alpha$-terpineol $(7.12-8.31 \%), \beta$-pinene (5.08- 8.41\%), Z- $\alpha$-trans-bergamotol (5.40-7.57\%), and caryophyllene oxide (4.12-7.11\%). The compounds $\alpha$-thujene, myrcene, and carvone disappeared during the drying time, reappearing days later. This difference may be due to a balance of composition among compounds, which makes the presence of the minor compounds undetectable. If the detection limit were reduced, these compounds would probably be detected at all drying times.
Results revealed that one day of leaves drying at $40{ }^{\circ} \mathrm{C}$ is enough to remove all moisture from the leaves without altering the content and chemical composition of the essential oil of Myrcia lundiana, which is crucial to avoid costs during the drying process.

\section{ACKNOWLEDGEMENTS}

The authors thank CNPq, FAPITEC/SE, CAPES, FINEP, and RENORBIO for providing the financial support of this work.

RESUMO: O objetivo do presente estudo foi avaliar o efeito do tempo de secagem das folhas no teor e na composição química do óleo essencial de M. lundiana. Testaram-se os tempos 0, 1, 2, 3, 4, 5, 6, 8 e 10 dias de secagem das folhas a $40^{\circ} \mathrm{C}$ em estufa com circulação forçada de ar. Os óleos essenciais foram obtidos por hidrodestilação, utilizando o aparelho Clevenger, e a análise da composição química foi realizada através de CG-MS/FID. A secagem das folhas de $M$. lundiana não provocou variações significativas no teor de óleo, variando de 1,18 a 1,51\%. O ácido nerólico foi o composto majoritário, variando de $27,8 \%$ no sexto dia de secagem a $35,64 \%$ no décimo dia de secagem. O composto 1,8-cineol foi identificado como o segundo componente principal do óleo, variando de 9,04\% a 14,01\%. Outros componentes observados no óleo essencial foram $\alpha$-terpineol $(7,12-8,41 \%)$, $\beta$-pineno $(5,08-9,03 \%)$, Z- $\alpha$-trans-bergamotol $(5,40-7,57 \%)$ e óxido de cariofileno $(4,12-7,11 \%)$. Um dia de secagem das folhas a $40{ }^{\circ} \mathrm{C}$ foi o suficiente para atingir o nível de umidade foliar recomendado, não alterando significativamente o teor e a composição química do óleo essencial de M. lundiana e nem os teores dos componentes majoritários do óleo essencial.

PALAVRAS-CHAVE: Planta aromática nativa. Constituintes Químicos. Secagem. Influência.

\section{REFERENCES}

ADAMS, R. P. Identification of essential oil components by gas chromatography/mass spectroscopy. 4th ed., Allured: Carol Stream, 2007. 804p.

ALVES, M. F.; BLANK, A. F.; ARRIGONI-BLANK, M. F.; FONTES, S. S.; JESUS, H. C. R.; ALVES, P. B. Establishment of methodology for drying leaves and storage of essential oil of linalool chemotype Ocimum basilicum L. Journal Bioscience, Uberlândia, v. 31, n. 5, p. 1441-1449, Sept./Oct. 2015. http://dx.doi.org/10.14393/BJ-v31n5a2015-22056

ALVES, M. F.; NIZIO, D. A. C.; SAMPAIO, T. S.; NASCIMENTO JUNIOR, A. F; BRITO, F. A.; MELO, J. O.; ARRIGONI-BLANK, M. F.; GAGLIARDI, P. R.; MACHADO, S. M. F.; BLANK, A. F. Myrcia lundiana Kiaersk native populations have different essential oil composition and antifungal activity against Lasiodiplodia theobromae. Industrial Crops and Products, Holanda, v. 85, p. 266-273, july. 2016. http// doi.org/10.1016/j.indcrop.2016.03.039

BORSATO, A. V.; DONI-FILHO, L.; PAGLIA, E. C. Propriedades físico-químicas do óleo essencial de camomila [Chamomilla recutita (L.) Rauschert] submetida à secagem em camada fixa. Revista Brasileira de Plantas Medicinais, Botucatu, v. 10, n. 3, p. 24 - 30, 2008.

http://www.sbpmed.org.br/download/issn_08_2/artigo5_v10n3.pdf

BLANK, A. F.; FONTES, S. M.; CARVALHO FILHO, J. L. S.; ALVES, P. B.; SILVA-MANN, R.; MENDONÇA, M. C.; ARRIGONI-BLANK, M. F. Influência do horário de colheita e secagem de folhas no óleo essencial de melissa (Melissa officinalis L.) cultivada em dois ambientes. Revista Brasileria de Plantas Medicinais, Botucatu, v. 8, n. 1, p. 73-78, jan. 2005.

http://www.sbpmed.org.br/download/issn_05_4/artigo14_v8_n1.pdf 
BLANK, A. F.; COSTA, A. G.; ARRIGONI-BLANK, M. F.; CAVALCANTI, S. C. H.; ALVES, P. B.; INNECCO, R.; EHLERT, P. A. D.; SOUSA, I. F. Influence of season, harvest time and drying on Java citronella (Cymbopogon winterianus Jowitt) volatile oil. Revista Brasileira Farmacognosia, Curitiba, v. 17, n. 1, oct./dec. p. 557-564, 2007. http://dx.doi.org/10.1590/S0102-695X2007000400014

CARVALHO-FILHO, J. L. S. C.; BLANK, A. F.; ALVES, P. B.; EHLERT, P. A. D.; MELO, A. S.; CAVALCANTE, S. C. H.; ARRIGONI-BLANK, M. F.; SILVA-MANN, R. Influence of the harvesting time, temperature and drying period on basil (Ocimum basilicum L.) essential oil. Revista Brasileira Farmacognosia, Curitiba, v. 16, n. 1, p. 24-30, jan./mar. 2006. http://dx.doi.org/10.1590/S0102695X2006000100007

COSTA, L. C. B.; CORRÊA, R. M.; CARDOSO, J. C. W.; PINTO, J. E. B. P.; BERTOLUCCI, S. K. V.; FERRI, P. H. Secagem e fragmentação da matéria seca no rendimento e composição do óleo essencial de capim-limão. Horticultura Brasileira, Brasília, v. 23, n. 4, p. 956-959, oct./dez. 2005. http://dx.doi.org/10.1590/S0102-05362005000400019

EHLERT, P. A. D.; BLANK, A. F.; ARRIGONI-BLANK, M. F.; PAULA, J. W. A.; CAMPOS, D. A.; ALVIANO, C. S. Tempo de hidrodestilação na extração de óleo essencial de sete espécies de plantas medicinais. Revista Brasileira de Plantas Medicinais, Botucatu, v. 8, n. 2, p. 79-80, 2006. http://ri.ufs.br/handle/123456789/1548

GOVAERTS, R.; SOBRAL, M.; ASHTON, P.; BARRIE, F. Word checklist of Myrtaceae. Royal Botanic Gardens, Kew. 2008, 455p.

IBAMA. Plano operativo de prevenção e combate aos incêndios florestais no Parque Nacional Serra de Itabaiana. Disponível em: www.ibama.gov.br. Acessado em 14 de outubro de 2016, 2006.

LUZ, J. M. Q.; EHLERT, P. A. D.; INNECCO, R. Horário de colheita e tempo de secagem da alfavaca-cravo. Horticultura Brasileira, Brasília, v. 27, n. 4, p. 539 - 542, oct./dez. 2009. http://dx.doi.org/10.1590/S010205362009000400022

NAGAO, E. O.; INNECCO, R.; MATTOS, S. H.; MARCO, C. A.; Influência do período de secagem nas estações seca e chuvosa no óleo essencial de Lippia alba (Mill) N.E.Br., nas condições do Ceará. Revista Ciência Agronômica, Fortaleza, v. 36, n. 1, p. 53-59, jan./abr. 2005.

http://www.ccarevista.ufc.br/seer/index.php/ccarevista/article/view/7/8

PARMAR, M. R.; KUMPAVAT, M. T.; DOSHI, J. S.; KAPDI, S. S. A comparative study on drying of basil leaves. Agricultural Engineering International: CIGR Journal, Índia, v. 19, n. 1, p. 169 - 177, june, 2017. http://www.cigrjournal.org/index.php/Ejounral/article/view/3867

ROSADO, L. D. S.; PINTO, J. E. B. P.; BOTREL, P. P.; BERTOLUCCI, S. K. V.; NICULAU, E. S.; ALVES, $\mathrm{P}$. B. Influence of leaf processing and type of drying on the content and chemical composition of the essential oil of basil cv. Maria Bonita. Ciência e Agrotecnologia, Lavras, v. 35, n. 2, p. 291-296, mar./abr., 2011. http://www.scielo.br/pdf/cagro/v35n2/a09v35n2

SANTANA, A. C. M.; PEREIRA, G. S.; BOAVENTURA, C. M.; UETENABARO, A. P. T.; COSTA, L. C. B.; OLIVEIRA, R. A. Rupture of glandular trichomes in Ocimum gratissimum leaves influences the content of essential oil during the drying method. Revista Brasileira de Farmacognosia, Curitiba, v. 24, n. 5, p. 524-530, Sep./Oct., 2014. https://doi.org/10.1016/j.bjp.2014.10.006

VAN DEN DOOL, H.; KRATZ, P. D. A generalization of the retention index system including linear temperature programmed gas-liquid partition chromatography. Journal of Chromatography, USA, v. 11, p. 463-471, aug. 1963. https://doi.org/10.1016/S0021-9673(01)80947-X 